Adu, K. O. \& Duku, N. Learning Styles and Instructional Materials as Correlates of Grade 6 Learners' Mathematics Performance in Buffalo City, South Africa

\title{
Learning Styles and Instructional Materials as Correlates of Grade 6 Learners' Mathematics Performance in Buffalo City, South Africa
}

\author{
Kemi Olajumoke Adu ${ }^{* 1} \&$ Ntombozuko Duku ${ }^{1}$ \\ *Corresponding Author: kemiadu78@yahoo.com \\ 1. Faculty of Education, University of Fort Hare, South Africa. \\ Received : 2021-09-29 \\ Revised : 2021-11-07 \\ Accepted : 2021-12-13 \\ $10.46303 /$ ressat.2021.41
}

How to cite this paper: Adu, K. O. \& Duku, N. (2021). Learning Styles and Instructional Materials as Correlates of Grade 6 Learners' Mathematics Performance in Buffalo City, South Africa. Research in Social Sciences and Technology, 6(3), $242-255$.

https://doi.org/10.46303/ressat.2021.41

This is an Open Access article distributed under the terms of the Creative Commons Attribution 4.0 International license (https://creativecommons.org/licenses/by/4.0/).

\begin{abstract}
Mathematics is a core subject in South Africa. Studies have shown that the performance of learners on this subject is not encouraging. Many factors have been alluded to by scholars as contributing factors to this poor performance. The gap between theory and practice of mathematics teaching can be bridged by the use of appropriate learning styles, availability, and utilization of instructional. This paper finds out the relationship that exists among learning styles, instructional materials, and mathematics performance of Grade 6. The choice of Grade 6 is important because it is the last grade level of primary school before a learner can enter secondary school level in South Africa. The study adopted a correlational research design of a quantitative approach. Stratified sampling techniques were used to select 1225 learners from Grade 6 schools within Buffalo City Metropolitan Education District. The data revealed among others that in Buffalo City, availability and utilization of instructional materials have no significant relationship with the mathematics performance of selected grade 6 learners $(B=.023$, $\mathrm{t}=.804, \mathrm{P} \geq 0.05$ ) while students learning styles (visual, auditory, and kinesthetic) have a significant relationship with grade 6 learners Mathematics performance $(B=-.113, t=-3.886$, $\mathrm{p}<0.05)$. The study concluded that one of the most fundamental issues to consider in improving Mathematics performance is the understanding of the learners' learning styles and effective use of appropriate instructional materials for teaching Mathematics.
\end{abstract}

Keywords: learning styles; instructional materials; mathematics; performance.

\section{Introduction}

Poor academic performance and a bad attitude toward mathematics among students are influenced by more than just teaching methods and instructional resources. Individual differences have been revealed as a pointer to the learning style demonstrated by learners during classroom teaching (Abdullahi, 2014). According to him, the transformation of 
Adu, K. O. \& Duku, N. Learning Styles and Instructional Materials as Correlates of Grade 6 Learners' Mathematics Performance in Buffalo City, South Africa

knowledge in a habitual way is defined as learning style. Psychological characteristics resulting from individual differences, according to Abdullahi (2014), determine the learning processes that a person employs. Learning styles, on the other hand, are qualities of the psychological, emotional, and cognitive domains that lyunade (2014) emphasizes as the accomplishment of desired learning outcomes due to proper engagement of learning. Furthermore, Dunn and Dunn (2011) believe that specific learning styles of individuals' emphasis on mental process, retention, and internalization of challenging material result in new and difficult information.

Concepts and ideas are easily distributed and appealing to the senses of the learners at any time when learners learn and process information in their unique way (Munchi, 2008). Students learn in different ways since it has been discovered that language structure acquisition has an impact on the brain shape of the students (lyunade, 2014). Similarly, the brain's hemispheres possess separate perceptual pathways. The differences in the style in which students perceived things are determined by the types of cells in their brain (lyunade, 2014; Munchi, 2008).

Learning style is characterized as attitudes and certain behaviors that assist learners during learning activities (Dunn \& Dunn, 2011). The personalities of the students are being influenced by the manner of interaction between teachers' teaching styles and students' learning styles. According to Dunn and Dunn (2011), learning styles that will increase the understanding of the subject matter and promote performance and enhance desirable outcomes must be identified by the teachers and the students. Learning style is defined as "how individuals begin to concentrate on, process, assimilate and remember new and difficult material" in this context (Hawk \& Shah, 2017, p. 9). Although each person is born with natural preferences for certain types, culture, personal experiences, age level, and development all have an impact on these biological or inherited characteristics in an individual (Savoury, 2014). Not only that, but the students' backgrounds might also play a role in the style they display. Style can be referred to as a "contextual" variable or construct since what the student adds to the learning experiences is both a component of the curriculum and a key feature of the learners' experience. Each learner perceives, organizes, and remembers information in their own unique and consistent way (Dunn \& Dunn, 2011). The gap between theory and practice of mathematics teaching can be bridged by the use of appropriate learning styles, availability, and utilization of instructional. Despite the importance of mathematics and its contribution to the growth and development of a nation, many learners still find it difficult to perform very well.

Mathematics is designed to help students develop a passion for basic skills in technology and science and to apply what they have learnt to their real-world and meet up with the requirements of society. A firm foundation in mathematics is required to accelerate any society's socioeconomic and technological advancement (Azuka, 2014). According to Kolawole (2010), a good foundation in mathematics at the elementary school level could help to mitigate the inadequacies of this subject at the university level. According to Nwichi (2013), teaching materials include a wide spectrum of visual and auditory media, ranging from simple chalkboard drawings to elaborate overhead projections. Despite the importance of instructional resources in the teaching and learning of Mathematics, many students continue to perform poorly. This could be due to a shortage of educational materials or teachers' underutilization of them. The teaching of any subject at the primary school level without the use of computers and transparency educational inputs, such as instructional resources will be 
Adu, K. O. \& Duku, N. Learning Styles and Instructional Materials as Correlates of Grade 6 Learners' Mathematics Performance in Buffalo City, South Africa

difficult Wales (2011) and Nwichi (2013) argue that the use of instructional materials and positive learning methods will help learners remember newly found data. It is possible to improvise instructional materials (SMASE Project, 2010).

Mntunjani (2016) stated that teachers need well-designed training on improvisation of instructional materials, such teachers must be creative and adventurous before they can improvise. The criterion for classifying learners, according to Felder and Henriques (2009), there are two sets of learners, some learners are intuitive while others are sensory, these two categories are referred to as perceptual behavior. Sensing learners are systematic and tangible; they excel at learning data and conducting hands-on work, and they are more at ease following norms and processes. 'Intuitive' learners are abstract and inventive, preferring novelty over repetition. Learners might be visual or verbal learners in terms of how they like to receive information. Visual learners prefer to get knowledge in the form of drawings, diagrams, videos, and demonstrations, whereas verbal learners prefer to absorb information through words. The researcher, on the other hand, believes that visual learners are superior to verbal learners since Chinese philosophers think that what learners see is remembered more than what they hear (Savoury, 2014). Aside from visual and verbal learners, there are also active and reflective learners to consider. As the name implies, an active learner enjoys being actively engaged in classroom activities. They participate actively in group discussions and engage with others, assessing and applying knowledge. Role-playing, teamwork, and discourse are beneficial to them. Reflective learners engage in in-depth thought and self-examination. They are more likely to think about anything they come across.

According to Mntunjani (2016), what is vital to teachers' daily activities is the use of appropriate pedagogy and the right instructional materials to discharge their professional duty and promote effective teaching and learning. In the same vein, to achieve the desired learning outcome, the teachers must play a critical role in ensuring that instructional materials (textbooks and other textual resources) are used. Textbooks, charts, graphs, workbooks, and illustrations are examples of instructional materials used in the teaching of mathematics (Mntunjani, 2016). "Instructional materials should arouse students' interest in learning Mathematics, help students to study Mathematics actively, develop students' potential in creativity through the process of learning basic knowledge, improve students' mathematical thinking when trying to understand the essence of mathematical knowledge, and raise students' awareness to apply mathematical knowledge in their everyday lives" (Lepik, 2015, p. 6).

The written curriculum resources such as textbooks, graphs, worksheets, calculators, etc. can be used with the teacher's instruction and support. In addition to these educational tools, computer-assisted tools play an important role in improving mathematics achievement at all levels of schooling (Adu, \& Duku, 2021). Textbooks are the most extensively used of all the written curriculum resources described above because they are most relevant and frequently used daily to teach mathematics and any other subject (Adu, 2018). Most teachers rely on mathematics textbooks to make decisions related to the stated objective or goal of each lesson. Another significance of the textbook is that it assists the teachers and students to reach compromise on the difficult tasks and to make resolution of challenges faced by both the teacher and students (Adu, 2018). 
Adu, K. O. \& Duku, N. Learning Styles and Instructional Materials as Correlates of Grade 6 Learners' Mathematics Performance in Buffalo City, South Africa

Poor academic performance and a bad attitude toward mathematics are influenced not just by teaching approaches, but also by learning styles. What led to poor performance is the obstructions that happened to effective classroom engagement due to misalignments that occur between learning and teaching styles (Mullis et al., 2012). Academic performance tends to increase when the teacher uses the right instructional materials that are commensurate with the learners' learning styles. Teachers frequently rely on instructional resources and learners' readiness when making decisions about what classroom activities to do and what assignments to offer students for them to understand mathematical information. When students can see, touch, smell, and even taste what they're learning, it becomes more captivating and interesting. This correlates with the Chinese proverb which reads: "What I see, I remember. What I hear, I forget and what I do, I understand." According to Opara (2012), learning materials are information carriers that are particularly created to meet the desired goals of the lesson. According to Okeke (2015, p. 289), instructional materials are:

All the physical (Synthetic and material that are real and spontaneous) resources are meant to be used by the facilitator in the process of teaching and learning. These materials may be used singly or in combination. In some cases, they could be used informally or formally.

This demonstrates that during classroom activities, teachers adjust their methods of using learning materials to effect changes in their learners' behaviors. The efficient use of instructional materials can certainly improve teaching and learning, arouse interest, and improve students' effective replies. According to Obara (2012), the development of cognitive, affective, and psychomotor domains in education is being determined by the ability of the teacher to meaningfully disseminate information that will arouse and appeal to the learners. Such will make the learners claim ownership of the subject matter and acquire more experiences.

Learning styles influence effective teaching and learning by determining learning behaviors. The learning environment can influence the learners' preferred learning style and behavior. Learners perceive, interact with, and respond to their surroundings in unique ways. The characteristics and personalities presented by their students, as well as the variances in their students' learning styles, must be the priority of the teachers, such characteristics and personalities can go a long way in assisting the teacher and make classroom activities more meaningful and more interactive (Adu et al., 2020). In addition, since the needs of the learners are different, the knowledge of learners' characteristics will assist the teacher to set up the classroom. When we consider a typical classroom setting, we rarely see all three of these learning modes (visual, aural, and kinesthetic) used together. While it may appear difficult, it is doable with careful teacher planning and preparation.

What learners see and hear affects their behavior, therefore the efficiency of learning is determined by what they see and hear. The organization and usage of instructional materials are critical for effective teaching and learning as well as concept retention. Sequel to the aforementioned point, Mkpa $(2015$, p. 15) believes that "learners remember $20 \%$ of what they hear, $30 \%$ of what they see, $50 \%$ of what they hear and see, $70 \%$ of what they hear, see and talk about, and $90 \%$ of what they hear, see, talk about and do". The utilization of instructional materials, according to Wales (2011) and Nwichi (2013), is what keeps discovered facts securely bonded to the learners' memories. 
Adu, K. O. \& Duku, N. Learning Styles and Instructional Materials as Correlates of Grade 6 Learners' Mathematics Performance in Buffalo City, South Africa

\section{Objective of the Paper}

The objective of the paper is to examine how learning styles and the utilization of instructional materials affect Grade 6 learners Mathematics performance in Buffalo City, South Africa.

\section{Research Questions}

The followings are the research questions guiding this paper.

- What is the relative effect of learning styles, availability, and utilization of instructional materials on grade 6 learners' Mathematics performance?

- What is the composite effect of learning styles, availability, and utilization of instructional materials on grade 6 learners Mathematics performance?

\section{Theoretical Framework}

This paper is anchored on a theory by Kolb, an American education theorist who proposed that experiential learning theory, self-initiative, and evaluation are the necessary skills under experiential learning. The availability of instructional materials coupled with appropriate learning styles promotes the two major skills. Experiential learning theory advocates for observations and experiments, these will lead to action plans and attainment of the stated goal. This comprehensive method enables students to acquire new skills in a variety of areas, including mathematics, as well as new characters. According to Kolb, learning has four stages: "do, observe, think, and plan," these stages encourage students to be active and not passive in their education (Akinoso, 2012).

According to Felder and Henriques (2009), learners in the classroom can be broadly divided into two; namely intuitive and sensory. Intuitive learners are curious, apt to learn difficult things, they are very inventive, creative, innovative and they prefer novelty regardless of what it entails, while sensory learners are very practical, always eager to carry out experiments, and engaging in empirical research before making any decision. Learners might be visual or verbal in terms of how they like to receive information, Visual learners prefer to get knowledge from what instructional materials are being displayed before them in class, whereas verbal learners prefer to engross in the information received from the teacher during the teaching. The researcher, on the other hand, believes that visual learners are superior to verbal learners since the learners always remember what they see than what they hear.

Furthermore, when it comes to the acquisition and processes of knowledge, the learners can be divided into two groups, namely, active and reflective. Active learners always like to be engaged in all classroom activities, they participated fully in class, they wanted to be noticed at all times. In any group work, they like to be the group leader. Always leading the conversation. On the other hand, the reflective learners are perceived learners waiting for the directives of the teacher before they can do anything. Reflective learners are using introspection, they always meditate and regurgitate what they are being taught without adding anything and dwell in perceived information. The learning behavior of the learners was influenced by their learning styles. Learners with varied learning style preferences will perceive, engage with, and react in different ways to the environment (Ma et al., 2013). Therefore, there is a need for teachers to understand and analyze the disparities that are conspicuous in the students' learning styles, this will allow the teachers to do justice to their differences during the teaching and learning 
Adu, K. O. \& Duku, N. Learning Styles and Instructional Materials as Correlates of Grade 6 Learners' Mathematics Performance in Buffalo City, South Africa

for better performance. Teachers will be able to understand the entry behavior of the students and assist them accordingly (Felder \& Spurlin, 2015).

The teaching and learning of mathematics using instructional materials are being described and appreciated by Kolb's learning theory (McGill \& Beaty, 2005). The following main ideas support this theory, which has a strong focus on learning, the concepts such as; experimenting, doing, and thinking are the reflective observation that leads to reflective observation, concrete experience, and abstract conceptualization. The use of concrete instructional materials, in line with Kolb's rationale, offers learners with practical opportunities to investigate and actively engage in the study of Mathematics. The use and the management of instructional materials allow students to experiment and learn via trial and error, allowing them to take charge of their education.

Furthermore, Kolb's notion of active implementation is in line with learning by doing through the use of instructional materials because learners learn differently. Some learners are learning by touching, while others by observation. What is imperative is that instructional materials ignite learners' abstract thinking and interests (reflective observation).

\section{Literature Review}

Teachers should be familiar with how to use the instructional materials to achieve the stated objectives of the lesson and facilitate classroom activities (Stein \& Kim, 2009). During the teaching-learning process, there is the necessity of employing a variety of instructional resources. A teacher has an important role to play in creating a learning experience that will allow students to understand some basic concepts in mathematics (Saleh et al., 2018). However, the efficiency of learning is determined by what learners see and hear. Effective teaching and learning with the ability to retain what is being taught is a result of the utilization and management of instructional materials. This is in line with lyunade (2014) that opined that designing instruction using a systemic approach will allow students to learn effectively. Moreover, other elements can promote effective teaching and learning, these are: (a) identifying instruction outcomes; (b) developing instruction; (c) evaluating instruction to ensure that it is effective. However, it has been found that an insufficient pedagogical approach makes the adaption of perfect school environments and the implementation of activities challenging. As a result, proper utilization of instructional materials is needed for the facilitation of teaching and achievement of learning objectives.

In South Africa and abroad, the application of learning strategies fosters the achievement of the learning goal. In addition, when a learner plans very well, such learner will be able to develop personality traits that can promote good rapport between the learner and the teacher, this makes an ideal classroom situation ( $M a \& M a, 2014$ ). Competitive students frequently regard everyone in the class as working toward the same learning goal. A learner who is referred to as competitive does not only want to be the first to reach the objective but also to achieve it more outstandingly than his or her classmates (Ma \& Ma, 2014). As a result, competitive learners frequently perceive academic success as when there are few achievers and many losers. Similarly, there is a competitive learning style that motivates learners to put up a lot of effort in their studies (Burguillo, 2010). Moreover, competitive learning has been 
Adu, K. O. \& Duku, N. Learning Styles and Instructional Materials as Correlates of Grade 6 Learners' Mathematics Performance in Buffalo City, South Africa

claimed by some educational psychologists to be undesirable since it causes excessive anxiety (Ma \& Ma, 2014).

Because of their age, a comprehensive description of a subject may not result in a greater grasp of that subject by primary school students; but, utilization of teaching materials for mathematics fascinates effective teaching and learning and remove ambiguity (lyunade, 2014). The usage of instructional materials at the primary level, according to Orhun (2013), has become a recognized fact all across the world. The "Modus Operandi" of utilizing and managing learning resources, on the other hand, has not been adopted. This means that teachers in primary schools use different methods for implementing and managing instructional materials, which has been noted as one of the problems of teaching and learning. In an ideal world, no effective education program would be possible without the necessary equipment, facilities, and resources.

People are not born with a predisposition to learn in a particular way; rather, through interaction with other people in the society and observing the norms of the society. However, certain styles of learning are universal across students worldwide. For example, if students are required to primarily reproduce knowledge on tests, memory will be the dominant learning technique (Ma \& Ma, 2014). Another thing that promotes the use of appropriate learning styles is culture. Some cultures are very distinctive and are on the premise of different assumptions. If these cultures are thoroughly observed, it promotes acceptable behavior that leads to standard learning styles which produce better performance

\section{Methodology}

\section{Research Approach and Design}

According to Adu and Duku (2021), a methodology is a process of selecting, reflecting on, analyzing, and justifying how a researcher wants to perform a research project. The research approach chosen for this paper is quantitative. It is quantitative because it looks at the relationship between or among variables. The variables in this paper are, learning styles, instructional materials, and mathematics performance. This paper now investigates how the independent variables affect the dependent variable (Olubela, 2015). The research design adopted for this paper is correlational, this design has the habit of investigating the relationship between variables. It gives the direction of a relationship between two or more variables. The direction of the relationship can be positive or negative, likewise significant and not significant. This design is very flexible (Adu \& Duku, 2021).

\section{Population and Sample}

The samples used for this paper are 1225 Grade, 6 learners, across 35 schools in Buffalo City. The sampling strategy adopted for this paper is stratified. Stratified sampling is a process of dividing the sample frame into strata to obtain relatively homogenous subgroups (Sanni, 2011). East London district consists of twelve (12) circuits, out of these; seven (7) circuits were randomly selected. A disproportionate stratified sampling strategy was used to select five (5) schools from each of the circuits. This gave 35 schools selected across all the circuits in the district. From each selected school, one arm of Grade 6 was also randomly selected and total enumeration was used to involve all the learners in the selected class. 
Adu, K. O. \& Duku, N. Learning Styles and Instructional Materials as Correlates of Grade 6 Learners' Mathematics Performance in Buffalo City, South Africa

\section{Research Instruments}

The students' learning style scale (SLSS) is a data collection tool with two sections: section A and section B. The biodata information in Section A includes Name, School, and Gender. There are seventeen (17) items in Section B, with the following response scales: GE = Great Extent, SE $=$ Some Extent, $\mathrm{LE}=$ Little Extent, $\mathrm{NA}=$ Not at All.

The Availability and Utilization of Instructional Materials Inventory (AUIMI), which has two components, sections $A$ and $B$, was also used to collect data for this work. Section A contains biographical information; Section $B$ has fifteen (15) items with the following response scales: A $=$ Available, $N A=$ Not Available if available, $U=$ Use, $N U=$ Not Use if not available. To determine the accuracy, usefulness, and credibility of the instrument, many domains of validity and reliability were used, including construct validity, content validity, and concurrent validity.

The last instrument is the Mathematics Achievement Test (MAT) which is a multiple-choice objective test made up of 25 items. Only one answer is correct among the multiple-choice of four ( $a, b, c, \& d)$. The test covers some topics in Mathematics. The scoring of MAT was done on a dichotomous basis. The correct response earned one mark, while an incorrect response earned zero. These instruments were administered to the learners.

\section{Validity and Reliability of Instruments}

The SLSS was validated by the experts in Mathematics education while its reliability was measured using Cronbach Alpha and a co-efficient value of 0.87 was obtained. The research instrument for (AUIMI) was originally presented to professionals in the field of Mathematics Education, who made the necessary adjustment to the instrument. The questionnaire was subjected to pilot testing to further give strong validity. The pilot activities were conducted in another location that is different from where samples were taken for the study. The researcher also used Cronbach alpha and it proved its dependability. and a coefficient value of 0.89 was achieved, indicating that the questionnaire was valid and had a good level of consistency.

The researcher constructed a pilot test of 25 items and administered it to 35 Grade 6 learners to measure its reliability coefficient using Kuder Richardson 20. This method makes use of psychometric data obtained from one test administration (Babbie, 2012). It is assumed that items in the instrument are homogeneous and so possess inter-item consistency. An instrument is reliable when it can produce consistently each time numerical results it is applied; not subject to variations except when there are changes in the variable being measured (Babbie, 2012; Sanni, 2011). The Kuder Richardson 20 was computed to determine the internal consistency and reliability of each item and the value was 0.78 . The instrument was given to experts in educational research (tests and measurement), and lecturers in Mathematics Education who offered suggestions, and corrections were affected to improve the instrument.

\section{Data Collection}

The data were collected using the aforementioned instruments. The researcher with the help of a research assistant administered the instruments to the respondents. The teachers also assisted in administering the MAT to their learners. Learners did the multiple-choice mathematics achievement test and submitted it after 40 minutes. The teachers also assisted to 
Adu, K. O. \& Duku, N. Learning Styles and Instructional Materials as Correlates of Grade 6 Learners' Mathematics Performance in Buffalo City, South Africa

mark the question papers and giving the score. The scores were used during data analysis by coding the different scores of the learners and correlating them with AUIMI

\section{Data Analysis}

Descriptive statistics of (percentage and frequency) and inferential statistics of multiple regression analysis were employed to answer the research questions. The software used for the analysis is Statistical Package for Social Sciences (SPSS). In this paper, the research questions that guided the study are adequately answered. The researcher coded the responses from AUIMI and the scores from MAT instruments before capturing and entering each item using SPSS.

\section{Result and Discussion}

\section{Demographic Characteristics/Information of Respondents}

The descriptive nature of this study necessitates the analysis of demographical information provided by the Grade 6 learners selected for the fieldwork. The biographical information (i.e. gender) is central to understanding the extent to which the outcome of this study could be generalized, and the learners' characteristics underlying the data analyzed in this study.

Table 1 below shows that 1225 Grade 6 learners participated in this study. 770 were female Grade 6 learners while 455 were males. The female Grade 6 learners that took part in the study were more than the male learners. $62.9 \%$ of the respondents are female learners while $37.1 \%$ were male learners.

Table 1. Information of Respondents

\begin{tabular}{lllcl}
\hline Gender & Frequency & Percent & Valid Percent & Cumulative Percent \\
\hline Male & 455 & 37.1 & 37.1 & 37.1 \\
Female & 770 & 62.9 & 62.9 & 100.0 \\
Total & 1225 & 100.0 & 100.0 & \\
\hline
\end{tabular}

\section{Research Question 1}

What is the relative effect of learning styles, availability, and utilization of instructional materials on grade 6 learners' Mathematics performance?

Table 2 shows that students learning styles (visual, auditory, and kinesthetic) have a significant relationship with grade 6 learners Mathematics performance $(B=-.113, t=-3.886, p<0.05)$. This result corroborates the assertions of Dunn, Beaudry, and Klavas (2009) that succinctly described that when learners were taught with the use of instructional materials with appropriate learning styles, success is inevitable. Even the low achievers will improve significantly. On the contrary, Bosman and Schulze (2018) believed that instructional materials and appropriate learning styles alone could not produce outstanding performance, that the only thing that can produce great achievements in mathematics is the combination of learning styles, teaching styles, and relevant instructional materials. 
Adu, K. O. \& Duku, N. Learning Styles and Instructional Materials as Correlates of Grade 6 Learners' Mathematics Performance in Buffalo City, South Africa

Table 2. Contributions of Independent Variables to Dependent variable.

\begin{tabular}{lccccccc}
\hline Model & $\begin{array}{l}\text { Unstandar- } \\
\text { dized } \\
\text { Coefficients } \\
\text { B }\end{array}$ & $\begin{array}{l}\text { Std. } \\
\text { Error }\end{array}$ & $\begin{array}{l}\text { Standardized } \\
\text { Coefficients Beta }\end{array}$ & T & Sig. & $\begin{array}{l}\text { Collinearity } \\
\text { Statistics } \\
\text { Tolerance }\end{array}$ & VIF \\
\hline 1 (Constant) & 14.128 & .508 & & 27.816 & .000 & & \\
$\begin{array}{l}\text { Students' } \\
\text { Learning Style }\end{array}$ & -.814 & .209 & -.113 & -3.886 & .000 & .957 & 1.045 \\
AUIMI & .0006 & .007 & .023 & .804 & .422 & .957 & 1.045 \\
\hline
\end{tabular}

Note. Dependent Variable: Mathematics performance

The same table shows that the availability and utilization of instructional materials have no significant relationship with the mathematics performance of selected grade 6 learners $(B=.023, t=.804, P \geq 0.05)$. This opposed the view of Ogundiran (2015), which confirmed in his study; that one of the problems facing or infringing on the academic performance of the pupils in Mathematics at public primary schools includes non-use of instructional materials. Limitation of available resources especially symbols and graphs etc. will affect the teaching of mathematics and make mathematics curriculum contents abstract (Erbilgin, 2017).

\section{Research Question 2}

What is the composite effect of learning styles, availability, and utilization of instructional materials on grade 6 learners Mathematics performance?

Table 3 presents the output of the multiple regression analysis computed to answer research question two. The regression outputs presented $R^{2}$ as $.012(1.2 \%)$, and $R=.110$, which implies that the students learning styles, availability, and utilization of instructional materials accounted for $1.2 \%$ of the variance in learners' Mathematics performance at schools in Buffalo city. This is in line with Adu et al. (2020), who opined that the significance of instructional materials cannot be overemphasized. The use of these materials with commensurate learning styles has a great deal in promoting or enhancing academic performance. Also, the use of the right learning styles is a key factor to the success of mathematics. These authors also believed that the use of adequate instructional materials always lays a good foundation for mathematics which the learners can build on. 
Adu, K. O. \& Duku, N. Learning Styles and Instructional Materials as Correlates of Grade 6 Learners' Mathematics Performance in Buffalo City, South Africa

Table 3. Combined effects of independent variables on the Dependent variable

\begin{tabular}{|c|c|c|c|c|c|c|}
\hline Model & $\begin{array}{l}\text { Sum of } \\
\text { Squares }\end{array}$ & Df & $\begin{array}{c}\text { Mean Square } \\
\text { VIF }\end{array}$ & $\mathrm{F}$ & Sig. & Remark \\
\hline 1 Regression & 243.990 & 2 & 121.995 & 7.552 & .001 & Significant \\
\hline Residual & 145.316 & 1222 & 16.153 & & & \\
\hline Total & 166.000 & 1224 & & & & \\
\hline \multirow[t]{2}{*}{${ }^{*} \mathrm{R}=.110$} & \multirow{5}{*}{\multicolumn{2}{|c|}{ Square $=.011$}} & Std. & & & \\
\hline & & & Error of & & & \\
\hline${ }^{* *}$ Adjusted $\mathrm{R}$ & & & Estimate & & & \\
\hline \multirow[t]{2}{*}{ Square $=.012$} & & & $=$ & & & \\
\hline & & & 4.01914 & & & \\
\hline
\end{tabular}

Note. Dependent Variable: Mathematics performance

Similarly, according to Adler and Pillay (2015), students learn more when the teacher does not use only a single approach but uses multiple approaches as a strategy to disseminate information. The researchers strongly believe that approach and learning styles are determined by the availability of instructional materials (Adler \& Pillay, 2015). According to lyunade (2014), learners are actively involved in classroom activities when there is an interplay between instructional materials and appropriate learning styles. He further argued that teaching styles play a fundamental role in ensuring the achievement of learning objectives in mathematics. Furthermore, Dunn and Dunn (2011) reiterated that learners without appropriate learning styles even if the resources are available are underachieving. This is in line with Ma et al., (2013) that the learning behaviour of the learners was influenced by their learning styles. Learners with varied learning style preferences will perceive, engage with, and react in different ways to the environment (Ma et al., 2013).

\section{Conclusion}

The study looked into the relationship between learning styles, instructional materials availability, and use, and Grade 6 Math achievement. Auditory, visual, and kinesthetic learners are examples of distinct types of learners. The auditory enjoys listening to the teachers and prefers to sit near them in class. Visual learners want to see things in person while learning. They learn through visual aids while Kinesthetic learns by doing. The study's findings demonstrated that all the learning styles in this study have a favorable impact on student's academic achievement in Mathematics. Nonetheless, visual learning approaches were found to be the most effective, because what the learner sees, the learner retains and understands better. This is supported by the philosophers who claim, "I recall what I see, but I forget what I hear." Teachers must play an important part in ensuring that students are shown what is relevant and can help them improve their performance. 
Adu, K. O. \& Duku, N. Learning Styles and Instructional Materials as Correlates of Grade 6 Learners' Mathematics Performance in Buffalo City, South Africa

\section{Recommendations}

The study found out that the variables under study are relevant to the academic performance of learners who undertake mathematics. The implication of this is that teachers need to recognize these styles and harmonize their styles with learners; styles to produce desirable results and outcomes. Teachers should also make use of appropriate materials and if need be, they can improvise. Mathematics is a unique subject that cannot be taught without instructional materials. Teachers should be trained by regular workshops to update their knowledge on the use of instructional materials and proper learning styles for effective teaching and learning. Effective classroom management is needed during the teaching of mathematics. In addition, teachers should be very flexible and align their teaching with the styles and the needs of the learners. A conducive environment is also needed apart from learning styles and materials.

\section{References}

Abdullahi, A. (2014). Mathematical knowledge for teaching fraction multiplication. Cognition and Instruction, 26(1), 95-143. https://doi.org/10.1080/07370000701798529

Adler, A. \& Pillay, H. (2015). Exploring student teachers' perceptions of the influence of technology in learning and teaching mathematics. South African Journal of Education, 35(4), 34-46. https://doi.org/10.15700/saje.v35n4a1217

Adu, K. O., Pylman, N., Adu, E. O., \& Duku, N. (2020). Instructional materials as a correlate of Grade 6 learners' mathematics performance in Buffalo City, South Africa. In M. Fabunmi, M. L. Quashie, E. O. Adu (Eds.). Multidisciplinary Research Reports from Africa (pp. 431-440). Global Education Network. https://globaledunet.org/wpcontent/uploads/2021/01/PROCEEDINGS-FINAL-.pdf

Adu, K. O. (2018). The use of textbooks by teachers in teaching mathematics at selected primary schools in East London Education District. (An unpublished dissertation submitted to Faculty of Education, University of Fort Hare, South Africa).

Adu, K. O., \& Duku, N. (2021). Gender and instructional materials as a correlate of Grade 6 learners' mathematics performance in Buffalo city, South Africa. Universal Journal of Educational Research, 9(3), 413-422. https://doi.org/10.13189/ujer.2021.090301

Akinoso, S. O. (2012). Effects of concrete-representational-abstract and explicit instructional strategies on senior secondary school students' achievement in and attitude to mathematics. (Unpublished Ph.D. Thesis University of Ibadan, Ibadan).

Azuka, B. F. (2014). Assessment in primary school mathematics classrooms in Nigeria. International Journal of Education Learning and Development, 2(2), 50-58

Babbie, L. (2012). Do ten-year-old children in Sweden know how they learn? A study of how students believe they learn compared to their learning style preferences. International Education Studies, 5(6), 11-23. https://doi.org/10.5539/ies.v5n6p11

Bosman, A. \& Schulze, S. (2018). Learning style preferences and mathematics achievement of secondary school learners. South African Journal of Education, 38(1), 1-15. 
Adu, K. O. \& Duku, N. Learning Styles and Instructional Materials as Correlates of Grade 6 Learners' Mathematics Performance in Buffalo City, South Africa

Burguillo, A. C. (2010). A Comparative study of public and private secondary schools in the provision of quality education. Journal of Educational Administration and Planning, 5, 88-95.

Dunn, R., \& Dunn, K. (2011). Teaching students through their individual learning styles. A practical approach. Prentice-Hall, Reston, VA.

Erbilgin, E. (2017). A Comparison of the mathematical processes embedded in the content standards of Turkey and Singapore. Research in Social Sciences and Technology, 2(1), 53-74. https://doi.org/10.46303/ressat.02.01.3

Felder, R. M. \& Henriques, E. R. (2009). Learning and teaching styles in foreign and second language acquisition. Foreign Language Annuals, 28(1), 21-31.

Felder, R. M. \& Spurlin, J. E. (2015). Application, reliability, and validity of the index of learning styles. Intl. Journal of Engineering Education, 21(1), 103-112. https://doi.org/10.1111/j.1944-9720.1995.tb00767.x

Hawk, T. F. \& Shah, A. J. (2017). Using learning style instruments to enhance student learning. Decision Sciences Journal of Innovative Education, 5(1), 1-19.

https://doi.org/10.1111/j.1540-4609.2007.00125.x

Iyunade, P.N. (2014). Refocusing the use of improvised educational media: A case of mathematics instruction in Imo State. Knowledge Review, 15(3), 45-50.

Kolawole, A. (2010). Practical use of ICT in science and mathematics teachers' training at DUCE (Master's thesis, University of Twente, The Netherland).

Lepik, M. (2015). Analyzing the use of textbook in mathematics education: The case of Estonia. Acta Paedagogica Vilnensia, 350, 90-102.

https://doi.org/10.15388/ActPaed.2015.0.9193

Ma, M. D. L., Monteiro, V., \& Peixoto, F. (2013). Attitudes towards mathematics: Effects of individual, motivational, and social support factors. Child Development Research, 876028. https://doi.org/10.1155/2012/876028

Ma, V. J. \& Ma, X. (2014). A comparative analysis of the relationship between learning styles and mathematics performance. International Journal of STEM Education, 1(3), 1-13. https://doi.org/10.1186/2196-7822-1-3

McGill, J. H., \& Beaty, S. (2005). Research in education: A conceptualintroduction. Boston: Little Brown and Company.

Mkpa, N. (2015). School-related strategies for winning more students to science and technology. BELSU Journal of education 1(1), 293 - 297.

Mntunjani, L (2016). The use of mathematical resources to teach number concepts in the foundation phase. (An unpublished dissertation submitted to faculty of education, Cape Peninsula University of Technology, South Africa).

Mullis, I. V. S., Martin, M. O., Goh, S., \& Cotter, K. (Eds.) (2016). TIMSS 2015 Encyclopaedia: Education Policy and Curriculum in Mathematics and Science. Boston College, TIMSS \& PIRLS International Study Centre website: 
Adu, K. O. \& Duku, N. Learning Styles and Instructional Materials as Correlates of Grade 6 Learners' Mathematics Performance in Buffalo City, South Africa

\section{http://timssandpirls.bc.edu/timss2015/encyclopedia/}

Munchi, N.T. (2008). Using the videotape instruction technique in teaching "saving your energy" Science Teachers Association of Nigeria Integrated Science Education Series, 6(36), 20-30

Nwichi, B. (2013). Teacher remuneration and productivity in Nigerian secondary schools. New York: Hill Int.

Obara, J. K. (2012). The efficacy of instructional media materials' utilization: Its implication to teaching. Nigerian Journal of empirical studies in psychology and Education. 1(16), 16 22.

Okeke, E. C. (2015). Instructional materials for environmental adult education: challenges for curriculum development in Nigeria. Nigerian journal of curriculum studies. 12(1), $288-$ 291.

Olubela, R.A (2015). Effect of Appreciative and Reflective Discourse Instructional Strategies on University Students Learning Outcomes in Citizenship Education Concepts in Social Studies in South-West Nigeria, Ibadan. (Unpublished Ph.D. Thesis, University of Ibadan).

Opara, M. (2012). The use of instructional materials in primary schools. Three days be on the full implementation of university basic education in Imo State. March 2002.

Ogundiran, S.O. (2015). Instructional materials' availability and utilization: implications on public primary school students' academic performance in Ibarapa North local government area of Oyo state. Journal of Educational Review, 8(1), 71-80.

Orhun, E. N (2013). Need for using instructional materials in junior secondary schools in Afikpo North. (Unpublished NCE Project Ebonyi State College of Education IKWO).

Saleh, S. F., Sudirman, P., Hidayanto, E. \& Susiswo, S. (2018) Elementary School Teachers' Mathematical Connections in Solving Trigonometry Problem. Research in Social Sciences and Technology, 3(3), 32-41. https://doi.org/10.46303/ressat.03.03.3

Sanni, S. (2011). Learning styles of prospective teachers: Kocaeli University case. Journal of Educational and Instructional Studies in the World, 3(2), 1-12.

Savoury, J. E. (2014). Class organization and administration. London: Nicholas and Coy Ltd.

SMASE Project (2010). Smase Training Program. Unpublished Raw Data. Smase project, Nairobi.

Stein, M. K. \& Kim, G. (2009). The role of Mathematics curriculum materials in large scale urban reform. In J. T. Remillard, B. A. Herbel-Eisenmann, \& G. M. Lloyd (Eds.), Mathematics teachers at work: Connecting curriculum materials and classroom instruction (pp.37-55). New York: Routledge.

Wales, F. (2011). Alternate funding of education. New York: Free Press. 